\title{
New host records for Sphenospora kevorkianii (Raveneliaceae)
}

\author{
Eliana Maria Rocha Sousa, Jaqueline Maria Oliveira do Nascimento, Juan Manuel Anda-Rocabado, Jorge Teodoro de \\ Souza
}

Recôncavo da Bahia Federal University, CCAAB, 44380-000 Cruz das Almas, BA

Author for correspondence: Jorge Teodoro de Souza (jgeteodoro@gmail.com)

Data de chegada: 13/05/2013. Aceito para publicação em: 25/09/2014.

$10.1590 / 0100-5405 / 1892$



Figure 1. A-J. Sphenospora kevorkianii Linder. A-B. Rust symptoms in leaves of Denfal muaug tai. A. Adaxial leaf side with pustules (arrow) $($ Bar $=10 \mathrm{~mm})$. B. Abaxial leaf side showing chlorosis $(\mathrm{Bar}=$ $10 \mathrm{~mm})$. C. Rust and anthracnose (arrow) symptoms in a leaf of $D$. muaug tai $(\mathrm{Bar}=10 \mathrm{~mm})$. D. Telial (T) and Uredinial (U) sori (arrows) in a Cyrtopodium aliciae leaf (Bar = $5 \mathrm{~mm}$ ). E-F. Tissue section showing Uredinia and Urediniospores. E. Section of a D. muaug tai leaf with an Uredinia (arrow) and Urediniospores $($ Bar $=50 \mu \mathrm{m})$. F. C. aliciae leaf showing Urediniospores (arrows) $(\mathrm{Bar}=10 \mu \mathrm{m})$. F-G. Urediniospores. G. Surface view showing spicules (arrow) $($ Bar $=10 \mu \mathrm{m})$. H. Median view showing wall thickness (arrow) $($ Bar $=10 \mu \mathrm{m})$. I-J. Teliospores I. Teliospore pedicel (arrow) $(\mathrm{Bar}=10$ $\mu \mathrm{m})$. J. Vertical septum (arrow) (Bar $=10 \mu \mathrm{m})$.

The Orchidaceae family is one of the largest among land plants; with approximately 800 genera, 35,000 species and 120,000 hybrids. Brazil is one of the centers of orchid diversity and endemism (Barros et al. 2012. http://floradobrasil.jbrj.gov.br/2012/FB000179). During surveys conducted in 2011 and 2012 for fungi pathogenic to orchids in Bahia State, two samples were found showing a rust fungus that was identified as Sphenospora kevorkianii Linder. There are six species in the genus Sphenospora, but only S. mera, S. saphena and S. kevorkianii have been recorded on orchids in Brazil. Twelve genera and 15 species of orchids are hosts for S. kevorkianii in Brazil (Carvalho Jr., A.A. 2012. http://floradobrasil.jbrj.gov.br/2012/FB094490).

Leaf samples with symptoms and signs of rust fungi were collected from the native species Cyrtopodium aliciae at Igatu Municipality (11 ${ }^{\circ} 42^{\prime} 45.18^{\prime}$ 'S - 40³7’32.95”W), Chapada Diamantina, Bahia State, on July 10, 2011. Samples of the commercial hybrid Denfal muaug tai were collected from the commercial nursery Orquidário Orquilândia Tropical, located at Camaçari Municipality (1248'35.64"S$\left.38^{\circ} 15^{\prime} 23.02^{\prime \prime} \mathrm{W}\right)$, on March 24, 2012. The samples were deposited in the RB herbarium of Rio de Janeiro Botanical Garden under the collector numbers 71 and 72 for D. muaug tai and C. aliciae, respectively.

Pustules on the leaves of $C$. aliciae were amphygynous and showed a waxy aspect, following the leaf veins; in D. muaug tai, pustules appeared on both sides, but were predominantly hypophyllous and had a flattened and pulverulent aspect. These pustules were orange to dark brown in both plant species. Spermagonia and aecia were not observed either in these samples or in any sample evaluated by other authors (Carvalho Jr., A.A. 2012. http://floradobrasil.jbrj.gov. br/2012/FB094490). Uredinia were conspicuous, sori amphygynous in $C$. aliciae, predominantly hypophyllous in D. muaug tai, showing orange color. Urediniospores were pale yellow, obovoid to ellipsoid, 20-32.5 x 17.5-24 $\mu \mathrm{m}$ with two equatorial germinative pores, yellow and equinulated walls $1-2 \mu \mathrm{m}$ thick. Telia were conspicuous, round and dark brown to black. Teliospore had 2 cells and a vertical septum, hyaline, ellipsoid, 19-28 x 12-15 $\mu \mathrm{m}$; no germinative pores were observed, smooth walls $1 \mu \mathrm{m}$ thick, hyaline pedicel, persistent up to $50 \mu \mathrm{m}$ long (Figure 1). Spores showed the same dimensions on both samples. The characteristics that allowed the separation of $S$. kevorkianii from the other Sphenospora species were number of germinative pores on urediniospores, wall thickness and size of the urediniospores, absence of paraphyses, size and thickness of the teliospore pedicel and thickness of the teliospore walls. Rust lesions may be invaded by Colletotrichum spp. and other fungal species, causing anthracnose that further contributes to the plant decline (Figure 1).

Sphenospora kevorkianii is the rust species most frequently found on orchids; however, this is its first report on C. aliciae and on the hybrid $D$. muaug tai, as it is the first time this rust species is found in Bahia State.

\section{ACKNOWLEDGEMENT}

JTS acknowledges CNPq for the productivity scholarship. 